\title{
Effect of Seasonal Variation on Correlation between Total Suspended Solids and Turbidity in Godavari River at Nashik
}

\author{
Vivek S. Wagh \\ Department of Civil Engineering \\ MET BKC IOE, Nashik, Maharashtra, India
}

\begin{abstract}
The Godavari River is a holy river. Apart from Ganga and Yamuna, Godavari is also one of the important religious rivers in India. Godavari is one of the sacred rivers in India. People all across country come to Nashik and take a holy bath to perform various religious activities especially in Kumbh Mela. Considering this some physicochemical properties of river Godavari at Nashik are studied. Temperature, pH, Turbidity, Total Suspended Solids (TSS), Total Dissolved Solid (TDS), Total Solids (TS), Dissolved Oxygen (DO) were determined during Monsoon (1st Sept to 17th Oct 2015), winter (18th to 29th Jan 2016) and Early Summer periods (29th March to 1st April 2016). The Godavari River is a second largest river in India originating from Trimbakeshwar, Nashik, Maharashtra, India. It flows through the states of Madhya Pradesh, Karnataka, Orissa and Andhra Pradesh. The study area covers the length of river starting from sampling point from where it enters the city to the point from where it leaves city along with three sub branches including the Nasardi Stream. There were 23 locations were selected for collection of water samples from the river and the samples were analyzed for water quality parameters. An attempt has been made to correlate TSS and Turbidity based on various seasonal conditions to offer more efficiency in predicting TSS concentration in study area. The traditional techniques were used to assess spatial and seasonal variations. Pearson's correlation test was used for correlating the data shows the positive relations between TSS and Turbidity $\left(R^{2}=0.722\right.$ from Sept to Oct $2015, R^{2}=0.554$ in Jan2016 \& $R^{2}=0.806$ from March to April 2016).
\end{abstract}

Keywords - Correlation, Godavari River, Total Suspended Solids. Turbidity.

\section{INTRODUCTION}

The domestic wastewater of the city was a major factor which is responsible for the contamination of the Godavari River (Bawa, 2013). The river, passing through Nasik City, is $82 \%$ polluted by domestic pollution and $18 \%$ by industries. (A. D. Chavan, 2009). Nashik city for satisfying domestic, agricultural, industrial demands depends mainly on River Godavari. The use of pesticides and chemical fertilizers in agricultural fields are responsible for deterioration of water quality of the river affecting physico-chemical parameters of the water. The survival of aquatic life is in danger due to the chemicals discharged into the river (Prakash Kadave, 2013).

\section{A. General -}

\section{MATERIALS AND METHODS}

Nashik is situated at Latitude $19^{\circ}-33^{\prime}$ and $20^{\circ}-53^{\prime}$ North with Longitude $73^{\circ}-16^{\prime}$ and $75^{\circ}-6^{\prime}$ East in Northern Maharashtra, at a height of 565 meters above mean sea level. The Godavari River flows through the city and has a length of $18 \mathrm{~km}$. For the investigation of Godavari River 10 sampling stations (A1 to A10) were selected along river within city and 3 sampling stations $(\mathrm{B} 1, \mathrm{~B} 2, \mathrm{~B} 3 \& \mathrm{C} 1, \mathrm{C} 2, \mathrm{C} 3)$ for each branch streams meeting river from North direction along with 7 sampling stations (D1 to D7) from South-West direction (Nasardi Stream) were selected to get representative samples of natural and polluted water. While testing the various TSS concentrations and Turbidity values in the same collection points of river the project was also studying whether the correlation between TSS and Turbidity can be established.

\section{B. Necessity -}

As we have discussed earlier that, the harmful pollutants in the Godavari River come through the residential, industrial, agricultural and commercial means and also as a holly river it may also contaminates due to religious activities too. The growing problem of degradation and human activities on river ecosystem has made it important to monitor water quality of rivers to evaluate their state of pollution. That's why it become prime important to predict the presence of suspended concentration in river in short time so that effective treatment can be applied to prevent 
river water pollution. This study will also help in predicting the nature of river water suspended solids concentration after simply knowing the turbidity of river water.

\section{Objectives -}

1. To perform the physico-chemical testing of river water from pre-defined sampling stations along the river and its sub-branches.

2. To analyze the test results and study their effect on TSS and Turbidity.

3. To find the correlation between TSS and turbidity by linear regression method.

4. To check the Turbidity as a surrogate for TSS concentration, to predict TSS concentration within short period in Godavari River at Nashik.

5. To study the correlation between TSS and Turbidity with seasonal variations

\section{METHODOLOGY}

For the completion of this project within stipulated time, following methodology has been adopted. During the project, standard procedures and precautions have been implemented as per IS 3025 (Part 38) - Reaffirmed 2003 for determination of Dissolved Oxygen, IS: 3025 (Part 16 and Part 17) for determination of Total Dissolved and Total Suspended Solids, IS 3025 (Part 15) - Reaffirmed 2003 for determination of Total Solids, IS 3025 (Part 10) Reaffirmed 2002 for determination of Turbidity.

1. Fixed the sampling locations along the river and branches by considering different locations as per development like agriculture, industrial, commercial, residential and public areas and their sanitary outlet points.

2. Coded the sampling points as A1, A2, A3 ... (Along Main stream), B1, B2, etc (Branch stream), C1, C2, etc (Branch stream) and D1, D2, etc (Branch stream).

3. Planned the sampling time and date at various sampling locations by considering seasonal variation. (Making 3 phase sampling wiz. Monsoon -1 st September 2015 to $22^{\text {nd }}$ September 2015 , winter $-18^{\text {th }}$ to $29^{\text {th }}$ Jan 2016 and summer $-29^{\text {th }}$ March to $1^{\text {st }}$ April 2016.)

4. Tagged the sampled at location with GPS for accuracy and uniformity in sampling during seasonal variations. (TABLE-I)

5. Lab tested of collected samples as per standard procedures and by following standard precautions for $\mathrm{pH}$, Turbidity, stream flow, Total Solids, TDS, TSS, DO and temperature as per planned dates and schedule.

6. Interpretation of physical observations and graphs along with correlations.

\section{IV.STUDY AREA}

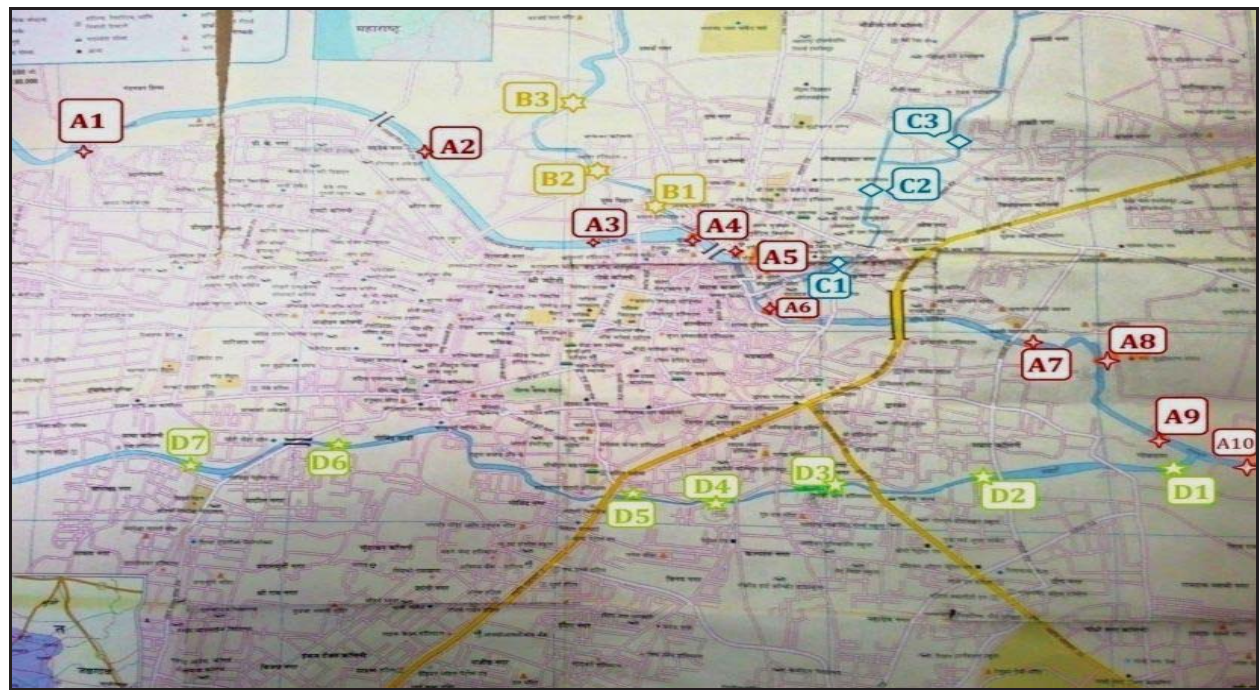

Figure.1 Map showing various sampling locations

The above map shows the various sampling locations within the study area for the analysis of Godavari River in Nashik city. Main stream samples along the river are designated by letters A1, A2 ...A10. In the study area there are three branches meets the river at different locations two to the left of main stream of river (Samples of which 
designated as B1, B2, B3 and C1,C2,C3) and one to the right also called Nasardi River (Samples of which designated as D1, D2, ... upto D7). The sampling locations along the river and branches are fixed as per development areas like agriculture, industrial, commercial, residential and public areas and their sanitary outlet points.

Table -1 G.P.S. Coordinates of Sampling Stations.

\begin{tabular}{|c|c|c|c|c|c|c|c|}
\hline Sample $\mathrm{St}^{\mathrm{n}}$ & Latitude & Longitude & Stream Type & Sample $\mathrm{St}^{\mathrm{n}}$ & Latitude & Longitude & $\begin{array}{l}\text { Stream } \\
\text { Type }\end{array}$ \\
\hline $\mathrm{A} 1$ & $20^{\circ} 11^{\prime} 10.06^{\prime \prime N}$ & 73.44'47.2"E & \multirow{10}{*}{ River } & $\mathrm{C} 1$ & $20^{\circ} 0^{\prime} 18.8^{\prime \prime} \mathrm{N}$ & $73^{\circ} 47^{\prime} 37.6 " \mathrm{E}$ & \multirow{3}{*}{$\begin{array}{c}2^{\text {nd }} \\
\text { Northern } \\
\text { Branch }\end{array}$} \\
\hline $\mathrm{A} 2$ & $20^{\circ} 1 ' 20.6^{\prime \prime} \mathrm{N}$ & $73^{\circ} 45 ' 21.2^{\prime \prime E}$ & & $\mathrm{C} 2$ & $20^{\circ} 0^{\prime} 18.4^{\prime \prime} \mathrm{N}$ & $73^{\circ} 47^{\prime} 37.9^{\prime \prime} \mathrm{E}$ & \\
\hline A3 & $20^{\circ} 0 ' 38.1 \mathrm{\prime N}$ & $73^{\circ} 47^{\prime} 07.7^{\prime \prime E}$ & & $\mathrm{C} 3$ & $20^{\circ} 0^{\prime} 18.2^{\prime \prime} \mathrm{N}$ & $73^{\circ} 47^{\prime} 38.3^{\prime \prime E}$ & \\
\hline A4 & $20^{\circ} 0 ' 39.2^{\prime \prime} \mathrm{N}$ & $73^{\circ} 47^{\prime} 18.6^{\prime \prime E}$ & & D1 & $19^{\circ} 59^{\prime} 21.2^{\prime \prime} \mathrm{N}$ & $73^{\circ} 49^{\prime} 21.3^{\prime \prime} \mathrm{E}$ & \multirow{7}{*}{$\begin{array}{c}\text { Southern } \\
\text { "Nasardi" } \\
\text { Stream }\end{array}$} \\
\hline A5 & $20^{\circ} 0^{\prime} 30.4^{\prime \prime} \mathrm{N}$ & $73^{\circ} 47^{\prime} 31.4^{\prime \prime} \mathrm{E}$ & & D2 & $19^{\circ} 59^{\prime} 19.5^{\prime \prime} \mathrm{N}$ & $73^{\circ} 49^{\prime} 20.7 " \mathrm{E}$ & \\
\hline A6 & $20^{\circ} 0^{\prime} 18.3^{\prime \prime} \mathrm{N}$ & $73^{\circ} 47^{\prime} 36.1^{\prime \prime E}$ & & D3 & $19^{\circ} 59^{\prime} 12.8^{\prime \prime N}$ & $73^{\circ} 47^{\prime} 53.9^{\prime \prime} \mathrm{E}$ & \\
\hline A7 & $20^{\circ} 00^{\prime} 01.6^{\prime \prime} \mathrm{N}$ & $73^{\circ} 48^{\prime} 39.9^{\prime \prime} \mathrm{E}$ & & D4 & $19^{\circ} 59^{\prime} 13.3^{\prime \prime} \mathrm{E}$ & $73^{\circ} 47^{\prime} 41.6 " \mathrm{E}$ & \\
\hline A8 & $22^{\circ} 00^{\prime} 00.7^{\prime \prime} \mathrm{N}$ & $73^{\circ} 48^{\prime} 49.5^{\prime \prime E}$ & & D5 & $19^{\circ} 59^{\prime} 08.7^{\prime \prime N}$ & $73^{\circ} 47^{\prime} 06^{\prime \prime E}$ & \\
\hline A9 & $19^{\circ} 59^{\prime} 19.5^{\prime \prime} \mathrm{N}$ & $73^{\circ} 49^{\prime} 28.6^{\prime \prime} \mathrm{E}$ & & D6 & $19^{\circ} 59^{\prime} 08.7^{\prime \prime} \mathrm{N}$ & $73^{\circ} 47^{\prime} 03.3^{\prime \prime} \mathrm{E}$ & \\
\hline A10 & $19^{\circ} 59^{\prime} 18.1 \mathrm{~N}$ & $73^{\circ} 49^{\prime} 34.3^{\prime \prime} \mathrm{E}$ & & D7 & $19^{\circ} 59^{\prime} 24.4^{\prime \prime} \mathrm{N}$ & $73^{\circ} 45^{\prime} 52.4^{\prime \prime} \mathrm{E}$ & \\
\hline B1 & $20^{\circ} 0^{\prime} 40.4^{\prime \prime} \mathrm{N}$ & 734'ㄱ'17.6"E & \multirow{3}{*}{$\begin{array}{l}1^{\text {st }} \text { Northern } \\
\text { Branch }\end{array}$} & & & & \\
\hline $\mathrm{B} 2$ & $20^{\circ} 0^{\prime} 40.5^{\prime \prime} \mathrm{N}$ & $73^{\circ} 47^{\prime} 17.2^{\prime \prime} \mathrm{E}$ & & & & & \\
\hline B3 & $20^{\circ} 0^{\prime} 40.7^{\prime \prime} \mathrm{N}$ & $73^{\circ} 47^{\prime} 16.8^{\prime \prime} \mathrm{E}$ & & & & & \\
\hline
\end{tabular}

\section{RESULTS \& DISCUSSIONS}

\begin{tabular}{|c|c|c|c|c|c|c|c|c|}
\hline $\begin{array}{c}\text { Stn. } \\
\text { No. }\end{array}$ & Temp & $\begin{array}{c}\text { Stream } \\
\text { flow }\end{array}$ & D.O. & Turbidity & TS & T.S.S. & T.D.S. & pH \\
\hline A1 & 30 & 100 & 7.6 & 3.8 & 350 & 70 & 280 & 7.25 \\
\hline A2 & 29 & 100 & 7.1 & 4.5 & 340 & 100 & 240 & 7.7 \\
\hline A3 & 29 & 100 & 6.9 & 6.8 & 380 & 160 & 220 & 7.2 \\
\hline A4 & 32 & 100 & 7.6 & 7.2 & 450 & 160 & 290 & 7.2 \\
\hline A5 & 30 & 100 & 7.15 & 8.1 & 535 & 165 & 370 & 7.685 \\
\hline A6 & 30 & 100 & 7.2 & 14.25 & 550 & 190 & 360 & 7.455 \\
\hline A7 & 29 & 100 & 7.1 & 15.15 & 610 & 240 & 370 & 7.52 \\
\hline A8 & 31 & 100 & 7 & 17.05 & 610 & 280 & 340 & 7.1 \\
\hline A9 & 31 & 100 & 5.9 & 17.85 & 680 & 300 & 380 & 7.405 \\
\hline A10 & 32 & 100 & 4.8 & 31.6 & 800 & 410 & 390 & 7.2 \\
\hline B1 & 30 & 30 & 3.2 & 12.1 & 380 & 240 & 140 & 7.47 \\
\hline B2 & 30 & 20 & 3.8 & 6.5 & 450 & 250 & 200 & 7.4 \\
\hline B3 & 29 & 20 & 4.1 & 2.5 & 310 & 100 & 210 & 7.41 \\
\hline C1 & 30 & 50 & 2.15 & 30.7 & 650 & 260 & 390 & 7.6 \\
\hline C2 & 28 & 30 & 3.1 & 27 & 590 & 340 & 250 & 7.45 \\
\hline C3 & 28 & 25 & 4.3 & 11.55 & 460 & 250 & 210 & 7.1 \\
\hline D1 & 31 & 60 & 2.05 & 19.2 & 630 & 230 & 400 & 7.545 \\
\hline D2 & 31 & 40 & 3.4 & 16.3 & 650 & 230 & 420 & 7.63 \\
\hline D3 & 31 & 30 & 4.2 & 8.8 & 575 & 200 & 375 & 7.6 \\
\hline
\end{tabular}




\begin{tabular}{|c|c|c|c|c|c|c|c|c|} 
D4 & 30 & 40 & 4.7 & 8 & 420 & 180 & 240 & 7.705 \\
\hline D5 & 30 & 80 & 5.25 & 7.65 & 340 & 175 & 165 & 7.345 \\
\hline D6 & 29 & 80 & 6 & 5.4 & 460 & 190 & 270 & 7.675 \\
\hline D7 & 30 & 100 & 7.1 & 4.005 & 420 & 120 & 300 & 7.585 \\
\hline
\end{tabular}

Table. 2. Test results for sampling during 1st Sept 2015 to 17th Oct 2015(phase-I)

During the sampling and testing following results were obtained. Entire results were divided into three phases of work based on the seasonal variations as mentioned earlier.

Results of Phase - I: During Monsoon some storm events were occurred during $1^{\text {st }}$ Sept 2015 to $17^{\text {th }}$ Oct 2015 so this sampling period was considered as a representative for Monsoon season. From the results in TABLE 2 it can be clearly observed that there was steep change in Turbidity as well as total solids concentration at sampling points A6, A7, A8, A9 and A10. This will possibly due to addition of distributaries and effluent discharge from STP Tapovan \& many untreated sewage disposal line along the main stream. Also the area under these stations is undeveloped and due to this during rainfall surface runoff caused huge concentration of suspended solids into river stream.

Also DO content was suddenly dropped beyond A8. This was due to the addition of contaminated waste water from Nasardi stream to the main stream of Godavari River. Besides this DO content was found very low for sampling points D1 to D7 along the Nasardi Branch from its meeting point towards origin side, due to heavy discharge of untreated waste water from slum area.

Another possible cause of this high low DO and high Total Solids content may be the low streamflow. Even at some locations it was nearly stagnant. But the sampling has been done during peak period so we will be able to get corresponding streamflow values. So the water quality for Nasardi was highly unsafe during that sampling period as DO content fall below $6.5 \mathrm{mg} /$ liter. Even at certain locations it falls below $4 \mathrm{mg} /$ litre which are harmful for aquatic life.

The $\mathrm{pH}$ values are nearly stable about 7 satisfying the requirements drinking water laid down by BIS i.e. 6.5 to 8.5. So there was no significant change as well as adverse effects were noted during this sampling period regarding $\mathrm{pH}$ examination.

Total Suspended Solids (TSS) and Total Dissolved Solids (TDS) concentrations were also found high than normal from A7 to A10. These locations were in the holy area of river where continuously the waste water came from various religious activities, bathing and also treated effluent from Tapovan STP.

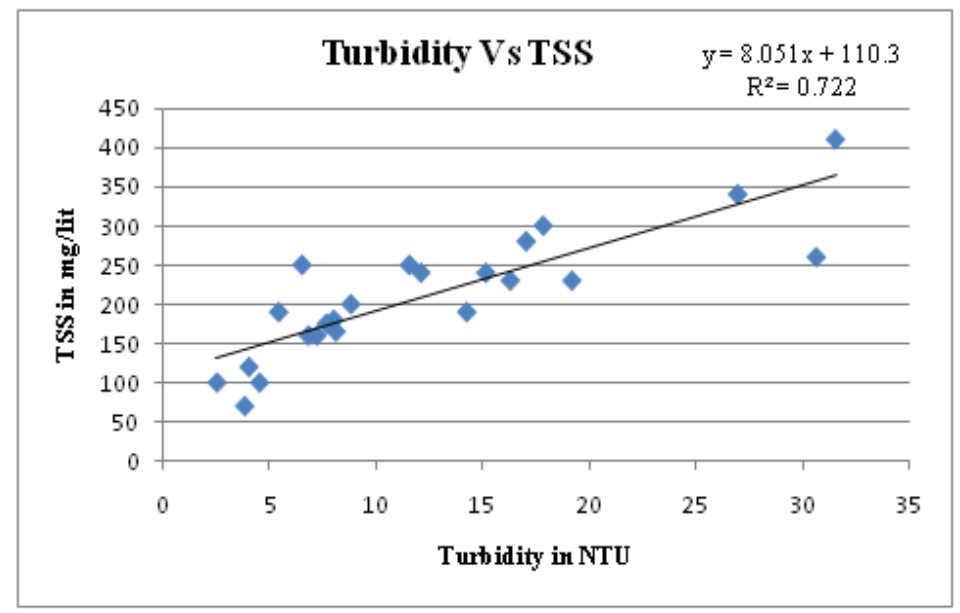

Figure .02 Correlation between TSS and Turbidity. (Phase-I)

From the above parameters some show good correlation with TSS like Turbidity, dissolved solids, Total solids. The TSS concentration and turbidity level were measured at the same collection point of river showing a large variance for the two parameters. The lowest and the highest TSS measurements were measured approximately at $70 \mathrm{mg} / \mathrm{lit}$ 
and $410 \mathrm{mg} /$ lit respectively. The lowest and the highest turbidity levels were recorded at 2.5 and 31.6 NTU respectively. As aforementioned, the selected data were then plotted in graph (Figure.02).

Correlation between TSS concentration (along y-axis) and turbidity level (along x-axis) of river streams was established after applying a linear regression model. In general, the graph show that an increase in TSS concentrations affecting in an increase in turbidity levels. Suspended solids have the ability to obstruct the transmittance of light in a water sample, when TSS concentration increases; light scattering intensifies. Figure.02 shows a good positive correlation between TSS concentration and turbidity level, with a correlation coefficient of $\mathrm{R}^{2}$ of 0.722 .

Results of Phase-II: In phase II all the tests mentioned above were done at the same collection point of river during winter season from 18th Jan. 2016 to 29th Jan. 2016. The correlation between TSS and Turbidity shows a moderately strong correlation. The lowest and the highest TSS measurements were measured approximately at 170 $\mathrm{mg} / \mathrm{lit}$ and $450 \mathrm{mg} / \mathrm{lit}$ respectively. The lowest and the highest turbidity levels were recorded at 5NTU and 91.6 NTU respectively. From the results shown in TABLE III it can be clearly observed that there was absence of dissolved oxygen at sampling points B2, B3, C2 and C3. This will possibly due to addition of highly contaminated effluent discharge from slum areas along the branch streams. Also during this phase almost at all the sampling stations shows very low DO than the minimum required as per drinking standards due which it was unsafe for drinking. The turbidity values are very high for sampling points B1, B2, B3 and C1, C2, C3 along the branch from its meeting point towards origin side, due to heavy discharge of untreated waste water from slum area.

In second phase, as like first phase keeping Turbidity as a dependent variable its correlations were established of which some shows strong positive relations while some shows weak as given below. The TSS concentration and turbidity level were measured at the same collection point of river as done in phase I with the samples from winter season. The graph below shows fairly positive correlation between TSS and Turbidity with the coefficient of correlation $\mathrm{R} 2=0.554$.

TABLE 3 Test Results For Sampling During $18^{\text {th }}$ JAN. 2016 - 29 $9^{\text {th }}$ JAN. 2016 (PHASE-II)

\begin{tabular}{|c|c|c|c|c|c|c|c|c|}
\hline $\begin{array}{c}\text { St }{ }^{\mathrm{n}} \\
\text { No. }\end{array}$ & Temp & $\begin{array}{c}\text { Stream } \\
\text { flow }\end{array}$ & D.O. & Turbidity & TS & T.S.S. & T.D.S. & $\mathrm{pH}$ \\
\hline A1 & 21.1 & 80 & 7.6 & 34 & 1144 & 364 & 780 & 7.3 \\
\hline A2 & 25.3 & 50 & 9.6 & 13.3 & 608 & 188 & 420 & 7.5 \\
\hline A3 & 21.9 & 90 & 7.7 & 21.3 & 920 & 250 & 670 & 7.38 \\
\hline A4 & 22.4 & 100 & 6.1 & 6 & 390 & 190 & 200 & 7.22 \\
\hline A5 & 23.8 & 100 & 5.7 & 5 & 490 & 170 & 320 & 7.51 \\
\hline A6 & 23.9 & 100 & 5.5 & 13.3 & 810 & 180 & 630 & 7.1 \\
\hline A7 & 26.6 & 100 & 7.8 & 12.1 & 942 & 230 & 712 & 7.43 \\
\hline A8 & 27.8 & 100 & 4.4 & 18.2 & 780 & 220 & 560 & 7.63 \\
\hline A9 & 25.6 & 100 & 5.2 & 29.1 & 810 & 355 & 455 & 7.6 \\
\hline A10 & 25.5 & 100 & 2.9 & 22.3 & 810 & 210 & 600 & 7.64 \\
\hline B1 & 28.4 & 30 & 1 & 50.1 & 920 & 230 & 690 & 7.15 \\
\hline B2 & 28.5 & 20 & 0 & 50.15 & 760 & 290 & 470 & 7.14 \\
\hline B3 & 28.4 & 20 & 0 & 52.2 & 1090 & 280 & 810 & 7.13 \\
\hline C1 & 26.4 & 50 & 1 & 91.6 & 1360 & 420 & 940 & 7.11 \\
\hline C2 & 25.2 & 30 & 0 & 76.7 & 1270 & 450 & 820 & 7.12 \\
\hline C3 & 26.7 & 25 & 0 & 73.1 & 1180 & 358 & 822 & 7.14 \\
\hline D1 & 24.7 & 60 & 5 & 25.3 & 860 & 260 & 600 & 7.35 \\
\hline D2 & 25.2 & 40 & 4.7 & 35.6 & 1050 & 340 & 710 & 7.23 \\
\hline
\end{tabular}




\begin{tabular}{|c|c|c|c|c|c|c|c|c|} 
D3 & 24.4 & 30 & 4.2 & 42.4 & 940 & 440 & 500 & 7.15 \\
\hline D4 & 25.1 & 40 & 3 & 29.8 & 720 & 290 & 430 & 7.3 \\
\hline D5 & 25.7 & 80 & 4.5 & 37 & 804 & 354 & 450 & 7.5 \\
\hline D6 & 26.2 & 80 & 3.6 & 21.6 & 1140 & 280 & 860 & 7.6 \\
\hline D7 & 23.2 & 100 & 2.9 & 26.5 & 795 & 345 & 450 & 7.1 \\
\hline
\end{tabular}

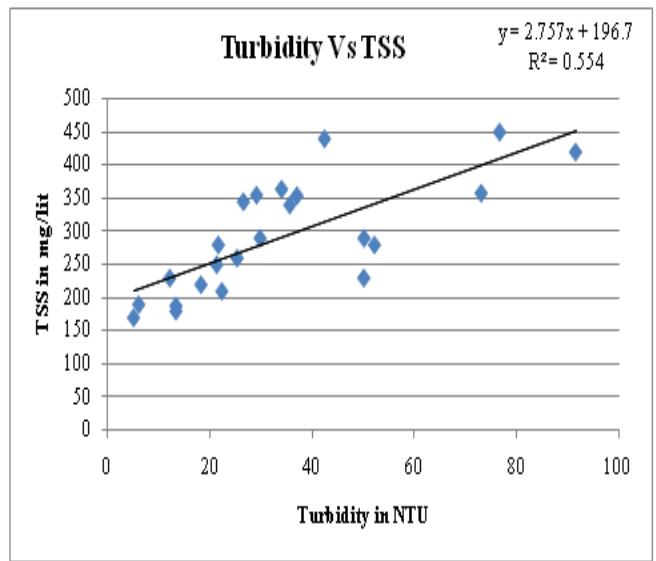

Figure 3. Correlation between TSS and Turbidity. (Phase-II)

Result of Phase- III: This was the last phase of sampling and testing the physico-chemical parameters of Godavari River water. This phase represented the early Summer Season sampling and testing. During this phase stream flow was very small or even at certain stations it was nearly stagnant. The samples were collected for testing depicting the realistic conditions. Below TABLE 4 shows the collective results for predefined parameters for fixed sampling locations. During this phase temperatures were recorded at very high than average temp of city. The highest temperature during this sampling period was $45.5^{\circ} \mathrm{C}$ while the lowest $35.2^{\circ} \mathrm{C}$. Also as shown in table below (TABLE $4)$, the rise in temperatures has affected the dissolved oxygen contents. The reason was simple that the more temperature will reduce the oxygen holding capacity of water.

On other hand at some sampling locations dissolved oxygen contents were recorded high. That would be due to growth of algae and similar aquatic plants in steady water. Also there were wide fluctuations in the turbidity results due to irregular stream flows. At station A5, A6 the turbidity, total solids and total dissolved solids were comparatively high. This was due to the small available flow for dilution and more anthropogenic activities near the bank of river, especially near Ramkunda and Tapovan area at A4, A5 and A6. Even $\mathrm{pH}$ at almost half the number of samples was alkaline in nature. At certain sampling locations it crossed the limits for drinking water.

In third phase as like phase I and phase II same parameters were tested at predefined sampling points during $29^{\text {th }}$ March 2016 to $1^{\text {st }}$ April 2016. The linear regression was attempted by considering turbidity as a dependent variable while the remaining were independent variables. Below graph (Figure 4) shows the correlation coefficients, regression equations along with regression lines on it.

TABLE 4 Test Results for Sampling during $29^{\text {th }}$ March to $1^{\text {st }}$ April 2016(PHASE-III)

\begin{tabular}{|c|c|c|c|c|c|c|c|c|}
\hline Stn & Temp & $\begin{array}{c}\text { Stream } \\
\text { flow }\end{array}$ & DO & Turbidity & TS & TSS & TDS & pH \\
\hline A1 & 45.5 & 10 & 9.8 & 1.9 & 1360 & 600 & 760 & 8.2 \\
\hline A2 & 38.6 & 10 & 11.3 & 12.7 & 1010 & 450 & 560 & 8.78 \\
\hline A3 & 35.9 & 20 & 4.7 & 35.7 & 1260 & 560 & 700 & 8.3 \\
\hline A4 & 38.2 & 60 & 7.7 & 97.1 & 3330 & 2500 & 830 & 8.49 \\
\hline
\end{tabular}




\begin{tabular}{|c|c|c|c|c|c|c|c|c|}
\hline A5 & 36.1 & 60 & 5.5 & 63.2 & 1600 & 1400 & 800 & 8.54 \\
\hline A6 & 37 & 60 & 5.4 & 73.9 & 2480 & 1500 & 980 & 8.26 \\
\hline A7 & 36.9 & 40 & 4 & 6.4 & 1300 & 350 & 950 & 8.03 \\
\hline A8 & 37 & 20 & 4.9 & 2.1 & 770 & 570 & 200 & 7.6 \\
\hline A9 & 42.8 & 50 & 4.1 & 15.6 & 810 & 340 & 470 & 7.76 \\
\hline A10 & 43.8 & 70 & 1.1 & 14.7 & 820 & 350 & 470 & 7.75 \\
\hline B1 & 36.3 & 30 & 1 & 59.3 & 2430 & 1430 & 1000 & 7.57 \\
\hline B2 & 36.5 & 30 & 0 & 90 & 3700 & 2800 & 900 & 7.62 \\
\hline B3 & 36.8 & 30 & 1.2 & 88.9 & 4350 & 3600 & 750 & 7.62 \\
\hline C1 & 36.3 & 40 & 2.7 & 91.6 & 4600 & 3400 & 1200 & 7.39 \\
\hline C2 & 36.5 & 30 & 2.3 & 44.7 & 2100 & 1000 & 1100 & 7.8 \\
\hline C3 & 36.8 & 40 & 0 & 42.2 & 1700 & 1920 & 500 & 7.67 \\
\hline D1 & 40.2 & 10 & 7.9 & 5.3 & 530 & 330 & 200 & 8.11 \\
\hline D2 & 41.5 & 10 & 10.4 & 10.2 & 720 & 220 & 500 & 8.42 \\
\hline D3 & 38.3 & 20 & 7.7 & 14 & 650 & 250 & 400 & 8.32 \\
\hline D4 & 37.2 & 25 & 5.8 & 26.5 & 1000 & 460 & 540 & 8.06 \\
\hline D5 & 35.2 & 20 & 6.5 & 27.2 & 620 & 370 & 250 & 8.09 \\
\hline D6 & 39.1 & 20 & 3.8 & 36.5 & 720 & 420 & 300 & 8.02 \\
\hline D7 & 38.6 & 10 & 3.3 & 27.6 & 800 & 360 & 440 & 7.67 \\
\hline
\end{tabular}

Below graph shows very strong positive correlation between TSS and Turbidity with regression coefficient of $\mathrm{R}^{2}=$ 0.806 during Phase - III. Out of remaining two phases this phase had shown relatively strong correlation. That may implies the use of turbidity as a surrogate to measurement of total suspended solids for same stream for limited area. Also many observations show maximum TSS concentrations as at many locations sampling was difficult due to less stream flow and even steady at some locations.

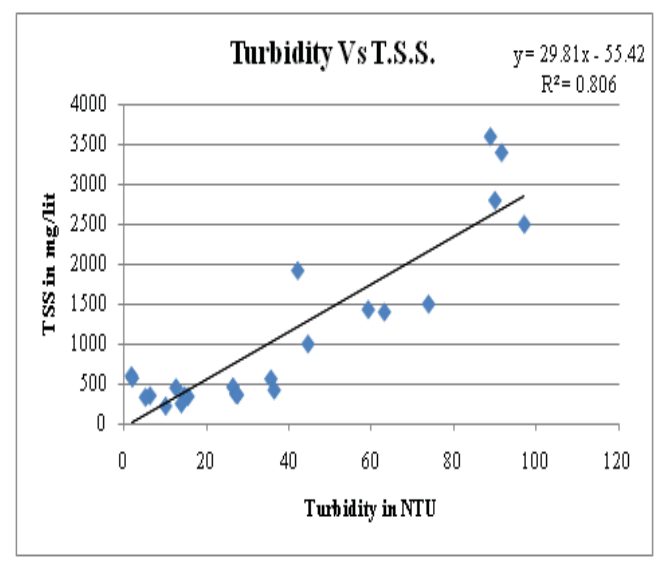

Fig.4 Correlation between TSS and Turbidity. (Phase-III)

\section{IV.CONCLUSION}

The data collected from 23 sampling stations along Godavari River shown a fairly good correlation $\left(\mathrm{R}^{2}=0.722\right.$ for Phase-I, $\mathrm{R}^{2}=0.554$ for Phase-II and $\mathrm{R}^{2}=0.806$ for Phase-III) between Turbidity levels and TSS concentrations. In present study, a good correlation between turbidity level and TSS have established, but the relationship can change 
spatially and temporarily due to variations in sediment composition in river streams, stream flow, temperature, catchment characteristics and many more.

Although the process of turbidity measurement is simpler and faster than the process of TSS measurement, more information is required to achieve more uniform result. Overall results for present study within prescribed study area suggest that the measurement of turbidity levels have the potential to replace the measurement of TSS concentrations if the area of study is strictly controlled.

Smaller scope of area of study, more data collections and controlled time of collection and analysis are required to better establish the correlation between TSS and turbidity in river streams. Proper planning, careful sampling and time bound study will be much helpful in establishing a good correlation between TSS and Turbidity. So from present study it may conclude that turbidity based on strong positive correlation, can be used as surrogate in the estimation of Total Suspended Solids concentration but within controlled area.

From the above study after referring test results and with reference to the conclusions and findings following points are recommended: Godavari River is a holly river. Many religious activities are continuously done in and around the river responsible for polluting river water besides discharge from much agricultural, industrial and municipal sewage units. The present study has shown very high concentration of turbidity, TDS and TSS along with depleted dissolved oxygen content than permissible. This is an alarming warning regarding the Godavari pollution. Therefore it needs some initiative efforts like proper planning of sewerage facility, upgrading the capacities or increasing the numbers of STPs, WTPs, planning for best Solid waste disposal systems.

Turbidity is the optical property of the water sample that causes light to be scattered and absorbed rather than being transmitted in straight lines. This property is affected by interaction between light and suspended particles in water. Therefore, turbidity could provide a good estimate of the concentration of TSS in a water sample, even though turbidity is not a direct measure of suspended particles in water. Past studies had been conducted showing consistently a strong correlation between TSS and turbidity. Thus, measuring turbidity in river water samples has shown a potential cost-saving option to estimate TSS concentration. However, using turbidity measurement to serve as a surrogate for TSS measurement was not recommended beyond the limited study area and duration. The main possible reason is, in water sample containing suspended solids; the light transmittance is depending on the above mentioned factors such as surface texture, size, shape, colour and reflectivity of the particles, etc. Also from public health concern by taking into consideration the pollution of Godavari river, it is recommended that water needs appropriate treatment and should not be consumed directly particularly within study area as turbid water is an indication of possible water contamination.

\section{REFERENCES}

[1] Christopher A. Ellison, "Correlating stream flow, turbidity, and suspended-sediment concentration in Minnesota's wild rice river", 2nd Joint Federal Interagency Conference, Las Vegas, N V, pp 1-10. June 27 - July 1, 2010

[2] C. P. Holliday, "Establishing the relationship between turbidity and total suspended sediment concentration", Georgia Water Resources Conference, Institute of Ecology, The University of Georgia, Athens, Georgia. pp. 1-3. April 23-24, 2003

[3] Low Hui Xiang Daphne, "Correlation between Turbidity and Total Suspended Solids in Singapore Rivers", Journal of Water Sustainability, Volume 1, Issue 3, December 2011, pp. 313-322, December 2011

[4] Prakash Kadave, "Water Quality Assessment of the River Godavari, At Ramkund," International Journal of Engineering and Science, ISSN: 2278-4721, Vol. 2, Issue 2, pp. 64-68, January 2013

[5] Bawa Kalpana V, "Water Quality Assessment of Godavari River at Nashik, India: Impact of Sewage and Industrial Wastewater", Universal Journal of Environmental Research and Technology, ISSN-2249-0256, Volume 3, Issue 4, pp. 452- 457. 2013

[6] Ajay D. Chavan, "Water Quality Assessment of the Godavari River”, Hydro Nepal, ISSUE NO. 5, pp. 31-34. JULY, 2009

[7] K.N. Irvine, "Turbidity, suspended solids, and bacteria relationships in the buffalo river watershed", Middle States Geographer, 2002, 35: pp.42-51.2002.

[8] James J. Packman, "Using turbidity to determine total suspended solids in urbanizing streams in the Puget lowlands", University of Washington, pp. 1-11.

[9] Mohammad Muqtada Ali Khan, "Estimating Turbidity and Total Suspended Solids to Measure Sediment Load in Kelantan River", Advances in Environmental Biology, 7(14), pp 4895-4900, December 2013.

[10] T. N. Wickramaarachchi, "Stream flow, Suspended Solids, and Turbidity Characteristics of the Gin River, Sri Lanka", ENGINEER - Vol. XXXXVI, No. 04, pp.43-51, 2013.

[11] Thackston, E. L, "Improved methods for correlating turbidity and suspended solids for monitoring" DOER Technical Notes Collection (ERDC TN-DOER-E8), U.S. Army Engineer Research and Development Centre, Vicksburg, MS. pp.1-12, 2000.

[12] Kai Li KWOH, "Investigating relationship of Nephelometric turbidity unit and total suspended solids with the inherent optical properties parameters derived from spectra reflectance", Applied Optics. Vol 41, pp. 5755-5772, 2002.

[13] Jack Lewis, “Turbidity-controlled suspended sediment sampling for runoff-event load estimation”, Water Resources Research, Vol. 32, No. 7, pp 2299-2310. July 1996 
[14] Laura Kusari, "The use of Turbidity and Total Suspended Solids Correlation for the Surface Water Quality Monitoring", International Journal of Current Engineering and Technology, Vol.3, No.4, ISSN 2277 - 4106, pp. 1311-1314. October 2013 